\title{
A new operation technique for uterine prolapse: Vaginally- assisted laparoscopic sacrohysteropexy
}

\section{Uterin prolaps için yeni bir operasyon tekniği: Vajinal asiste laparoskopik sakrohisteropeksi}

\author{
İlhan Sanverdil, Çetin Kılıççı1, Mesut Polat ${ }^{1}$, Enis Özkayal, Sami Gökhan Kılıç², Merve Dizdar³, \\ Ateş Karatekel \\ ${ }^{1}$ University of Health Sciences, Zeynep Kamil Women and Children's Health Training and Research Hospital, Clinic of Obstetrics and Gynecology, \\ İstanbul, Turkey \\ ${ }^{2}$ The University of Texas Medical Branch, Department of Obstetrics and Gynecology, Division of Female Pelvic Medicine and Reconstructive \\ Surgery/Urogynecology, Texas, USA \\ 3 University of Health Sciences, Ümraniye Training and Research Hospital, Clinic of Obstetrics and Gynecology, İstanbul, Turkey
}

\begin{abstract}
Objective: To describe the new surgical technique and report the safety and feasibility of vaginally-assisted laparoscopic sacrohysteropexy (VALSH), Materials and Methods: Thirty-three women with stage 3 or more uterine prolapse underwent VALSH operation. Patients were followed up for 12 months for mesh-related complications and improvements of symptoms. The operation had three sections; $1^{\text {st }}$ laparoscopic, $2^{\text {nd }}$ vaginal, $3^{\text {rd }}$ laparoscopic. Results: The mean age, gravidity, and parity of the study population were 46.5 years (range, 25-68 years), 4.3 (1-9), and 2.9 (1-6), respectively. The mean duration of operation was $59.5 \mathrm{~min}$ (range, 20-120 min). There were significant differences between the pre- and post-operative values of pelvic organ prolapse quantification parameters, which were favorable in the latter evaluation ( $p<0.001$ ); total vaginal length was preserved after surgery ( $p>0.05$ ).

Conclusion: VALSH is a safe and minimally-invasive procedure in uterovaginal prolapse, with favorable anatomic and functional outcomes at 12 months post-operatively.
\end{abstract}

Keywords: Sacrohysteropexy, laparoscopy, vaginally-assisted laparoscopic sacrohysteropexy

$\ddot{O} z$

Amaç: Yeni bir cerrahi yöntem tanımlamak ve vajinal asiste laparoskopik sakrohisteropeksi (VALSH) operasyonunun güvenilirliği ve yapılabilirliğini rapor etmektir.

Gereç ve Yöntemler: Evre 3 veya daha ileri düzeyde uterin prolapsusu olan 33 hasta VALSH operasyonuna alındı. Hastalar meşe bağlı komplikasyonları ve semptomları değerlendirme amaçlı 12 ay takip edildi. Operasyonun üç bölümü vardı: 1. laparoskopik, 2. vajinal, 3. laparoskopik.

Bulgular: Çalışma grubunda ortalama yaş, gravidite, ve parite sırası ile 46,5 yll (25-68 yll), 4,3 (1-9), ve 2,9 (1-6). Ortalama operasyon süresi 59,5 dk (aralık, 20-120 dk). Sonraki değerlendirmede daha iyi olmak üzere, operasyondan önceki ve sonraki pelvik organ prolapsus-sınıflaması değerlerinde anlamlı fark izlendi ( $\mathrm{p}<0,001)$; total vajinal uzunluk cerrahi sonrası korundu $(\mathrm{p}>0,05)$.

Sonuç: VALSH uterovajinal prolaps tedavisinde güvenli ve minimal invaziv, anatomik ve fonksiyonel sonuçlanı iyi olan bir prosedürdür. Anahtar Kelimeler: Sakrohisteropeksi, laparoskopi, vajinal asiste laparoskopik sakrohisteropeksi

\footnotetext{
Address for Correspondence/Yazışma Adresi: Enis Özkaya, MD,

University of Health Sciences, Zeynep Kamil Women and Children's Health Training and Research Hospital, Clinic of Obstetrics and Gynecology, İstanbul, Turkey

Phone: +90 5054742459 E-mail: enozkaya1979@gmail.com ORCID ID: orcid.org/0000-0001-6580-1237

Received/Geliș Tarihi: 22.05.2017 Accepted/Kabul Tarihi: 30.08.2017
}

${ }^{\oplus}$ Copyright 2017 by Turkish Society of Obstetrics and Gynecology

Turkish Journal of Obstetrics and Gynecology published by Galenos Publishing House 
PRECIS: Vaginally-assisted laparoscopic sacrohysteropexy is a safe, minimally-invasive procedure in uterovaginal prolapse. Twelve months postoperatively, this procedure showed favorable anatomic and functional results.

\section{Introduction}

Uterovaginal prolapse is a frequently encountered condition especially among older women, which may lead to disability and poor quality of life $e^{(1)}$, and it is a major indication for gynecologic surgery. The lifetime risk for a woman to have uterine prolapse surgery is $11 \%{ }^{(1)}$. Risk of developing this kind of disorder increases with advancing age ${ }^{(2)}$. Surgery should be performed to restore anatomy with minimal morbidity and the lowest risk of recurrence. Three different approaches have been introduced to repair the pelvic floor such as abdominal, vaginal, and laparoscopic techniques. Hysterectomy is still considered to be the standard procedure for correcting uterovaginal prolapse ${ }^{(3)}$; however, in the majority of cases, hysterectomy does not overcome abnormalities associated with weakened pelvic support structures such as uterosacral and cardinal ligaments ${ }^{(4)}$. Additionally, due to the belief that the uterus plays a role in sexual satisfaction, an increasing number of women avoid undergoing hysterectomy ${ }^{(5)}$. Hysterectomy was shown to be associated with increased morbidity, blood loss, operative time, and influence postoperative recovery time ${ }^{(6)}$. Sacrospinous hysteropexy has been proposed to be an alternative approach for uterine-preserving prolapse surgery ${ }^{(7)}$. Other management alternatives include transvaginal mesh kits ${ }^{(8,9)}$, abdominal sacrohysteropexy using mesh $^{(10)}$, and laparoscopic uterine suspension using a sling ${ }^{(11)}$ or mesh ${ }^{(12)}$. A modified form of uterine-preserving prolapse surgery using a combined vaginal and laparoscopic approach was introduced and a series of 70 women was reported by Fayyad and Siozos ${ }^{(13)}$.

In this case series, we describe the safety, feasibility, and outcomes of a modified form of a combined vaginal and laparoscopic approach, vaginally-assisted laparoscopic sacrohysteropexy (VALSH) for treating advanced uterovaginal prolapse.

\section{Materials and Methods}

This study is a descriptive prospective case series of 33 women with symptomatic stage 3 or 4 uterine prolapse on the pelvic organ prolapse-quantification (POP-Q) prolapse examination system $^{(14)}$ who underwent VALSH between 2012 and 2015 in Zeynep Kamil Women and Children's Health Training and Research Hospital. The procedure was approved by the Zeynep Kamil Women and Children's Health Training and Research Hospital Local Ethics Committee (approval number: 2015/195) and informed consent forms were obtained from each patient. This new alternative of surgical intervention was offered to women with advanced uterine prolapse.

Inclusion criteria were as follows:

(1) Symptomatic uterine prolapse > stage 3; (2) symptoms of pelvic organ prolapse such as vaginal bulge and heaviness.
Women were asked to empty their bladder before examination. All examinations were performed while the women were in the lithotomy position. The women were asked to perform a maximum Valsalva maneuver before genital examination. Stages of uterine prolapse were determined according to the POP-Q classification. Preoperatively, all patients underwent POP-Q questionnaires to assess prolapsed-related symptoms ${ }^{(15)}$. After determining the surgical indication and following preoperative preparations, the procedure was performed under general anesthesia with the patient initially in the lithotomy position. Thirty-three women with stage 3 or more uterine prolapse underwent VALSH operations. Patients were followed up over a 12-month period after surgery for mesh-related complications and improvements of symptoms.

The operation consisted of three sections; $1^{\text {st }}$ laparoscopy, $2^{\text {nd }}$ vaginal, $3^{\text {rd }}$ laparoscopy. Laparoscopic ports were placed; one 10 -mm port for umbilical and two or three $5-\mathrm{mm}$ ports for lateral or suprapubic sites based upon conditions in order to achieve optimal surgical site exposure. The peritoneum over the sacral promontory was incised. A small $5-\mathrm{cm}$ tunnel was made underneath the peritoneum from the sacral promontory downward to the cervix. Then, a lightweight type of mesh was placed onto the promontorium surface.

Second, the vaginal part of the surgery was performed. A semicircular incision was made at the posterior cervicovaginal junction. Curved ring forceps were placed into the retroperitoneal area via a tunnel established through blunt dissection from the vaginal part towards the promontory. At the same time, the direction of the instrument was visualized via laparoscopy (Figure 1). When the tip of the ring forceps was observed through the incision in the promontorium, the mesh was grasped and pulled downward within the tunnel with the aid of an instrument. The mesh was then fixed onto the posterior face of the uterine cervix using 3-4 non-absorbable

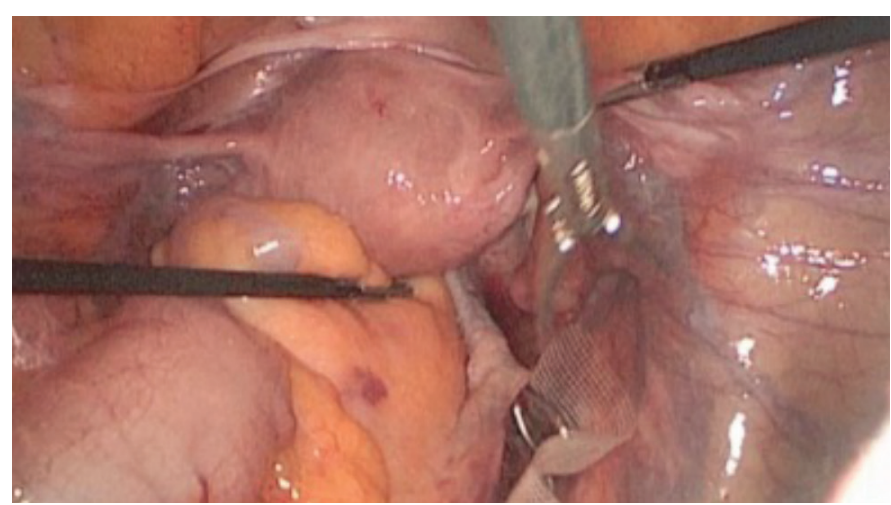

Figure 1. Laparoscopic view of curved ring forceps put into the retroperitoneal space via incision performed on the posterior wall of cervix 


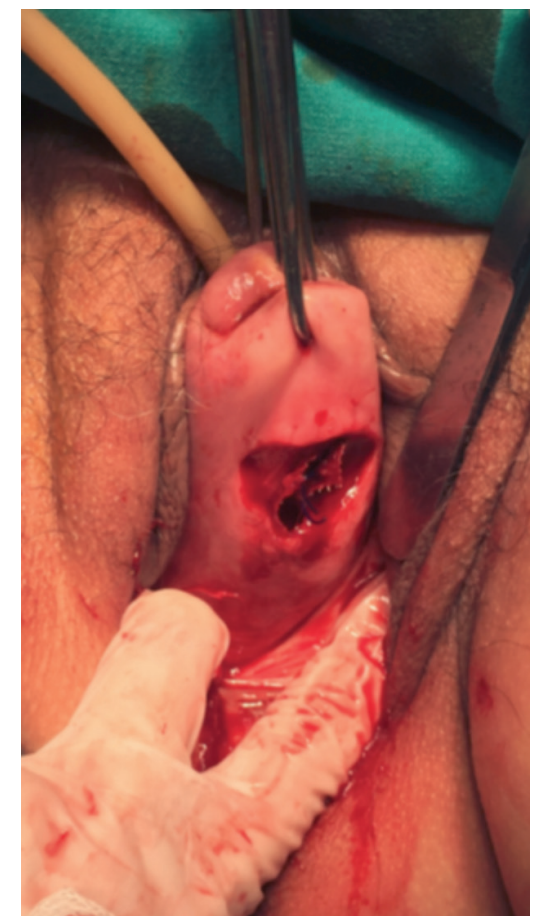

Figure 2. Cervical incision performed on the posterior wall where curved ring forceps are introduced and later mesh is fixed by 2-0 non-absorbable sutures $\mathrm{x} 4$ sutures via the vaginal route (Figure 2). The vaginal incision was closed by absorbable sutures.

Finally, the uterus was pushed up to the maximum level using a Rubin's cannula to obtain the required uterine suspension and mesh was tacked/sutured to the anterior longitudinal ligament at the sacral promontory and the peritoneal membrane over the promontory was sutured via the laparoscopic approach. A transobturator tape insertion procedure was applied in patients with stress urinary incontinence diagnosed before the operation through appropriate urogynecologic tests. A post-operative examination was performed in the lithotomy position using the POP-Q system. Mesh complications including mesh exposure were noted.

\section{Statistical Analysis}

Data were analyzed using SPSS version 15.0 for Windows (SPSS Inc., Chicago, Illinois). The pre- and post-operative data were compared using the Wilcoxon t-rank test, and p values of $<0.05$ were considered significant.

\section{Results}

The mean age, gravidity, and parity of the study population were 46.5 years (range, 25-68 years), 4.3 (1-9), and 2.9 (1-6), respectively (Table 1 ). The mean operation time was $59.5 \mathrm{~min}$ (range, 20-120 min). Pre- and post-operative symptoms are

Table 1. Summary of some demographic features of the study population

\begin{tabular}{llllll} 
& $\mathbf{n}$ & Minimum & Maximum & Mean & Standard deviation \\
\hline Age (years) & 33 & 25.0 & 68.0 & 46.5 & 10.3 \\
BMI $\left(\mathrm{kg} / \mathrm{m}^{2}\right)$ & 33 & 21.00 & 33.00 & 28.5 & 3.5 \\
Gravidity & 33 & 1.0 & 9.0 & 4.3 & 1.8 \\
Parity & 33 & 1.0 & 6.0 & 2.9 & 1.2
\end{tabular}

BMI: Body mass index

Table 2. Summary of pre- and post-operative urogynecologic symptoms of the whole study population

\begin{tabular}{|c|c|c|c|c|c|}
\hline & \multicolumn{4}{|c|}{ Symptoms } & \multirow[b]{3}{*}{$\mathrm{p}$} \\
\hline & \multicolumn{2}{|c|}{ Pre-operative } & \multicolumn{2}{|c|}{ Post-operative } & \\
\hline & Frequency & Percent & Frequency & Percent & \\
\hline Difficult defecation & 3 & 9.1 & 1 & 3 & \\
\hline Stress urinary incontinence & 1 & 3.0 & 0 & 0 & \\
\hline Stress urinary incontinence, mass protruding from vagina & 4 & 12.2 & 0 & 0 & \\
\hline Stress urinary incontinence, difficult defecation & 1 & 3.0 & 1 & 3.0 & \\
\hline Difficult defecation and urination & 2 & 6.1 & 0 & 0 & $<0.05$ \\
\hline Mass protruding from vagina with Valsalva & 15 & 45.4 & 0 & 0 & \\
\hline Stress urinary incontinence, difficult urination & 4 & 12.1 & 2 & 6.1 & \\
\hline Frequency, stress urinary incontinence & 2 & 6.1 & 1 & 3 & \\
\hline Constipation, mass protruding from vagina & 1 & 3.0 & 0 & 0 & \\
\hline Total & 33 & 100.0 & 33 & 100.0 & \\
\hline
\end{tabular}


shown in Table 2. The comparison of pre- and post-operative hemoglobin levels with the parameters of POP-Q values are summarized in Table 3. The rates of pre-operative prolapse stages were $4 \mathrm{Ba}(\mathrm{n}=12,36.3 \%)$, stage $4 \mathrm{C}(\mathrm{n}=10,30.3 \%)$, stage 3 Ba $(n=3,9.1 \%)$, stage $3 C(n=3,9.1 \%)$, stage 4 Bp $(n=2,6.1 \%)$, stage $4 D(n=2,6.1 \%)$, and stage 3 Bp $(n=1,3 \%)$. There were significant differences between the pre- and post-operative values of POP-Q parameters, which were favorable in the latter evaluation $(\mathrm{p}<0.001)$; total vaginal length was preserved after surgery ( $p>0.05$ ). Among 33 women, stress urinary incontinence was determined in 12 patients by prolapse reduction testing (36.4\%) managed by combined VALSH and transobturator tape insertion procedures. No perioperative complications were observed. There were five patients with cervical elongation concomitant with the uterine prolapse. At 12 months after surgery, all 33 patients reported cure of their prolapse symptoms with a subjective cure rate of $100 \%$. None of the patients developed de novo urgency, infection or mesh erosion following surgery during the follow-up period. On assessing the patients' global impression of improvement, all 33 women reported feeling either "very much better" or "much better." No recurrence or mesh complication was observed after 12 months' follow-up.

\section{Discussion}

In this case series, we wanted to show the feasibility of a new technique of VALSH. Data from our series show this technique to be feasible, safe, and easy to perform. It has several advantages over conventional techniques and recently introduced new vaginal-assisted laparoscopic approaches. There is still no consensus on the optimal management of advanced uterine prolapse. Vaginal hysterectomy has been proposed to be a standard procedure in these cases. In order to avoid removing a healthy organ and increasing morbidity and mortality with the hysterectomy procedure and also preserve fertility, uterinepreserving approaches were introduced a few decades ago ${ }^{(10-12)}$. With the recent advances in endoscopic surgery, some laparoscopic uterine suspension techniques have been described $^{(16-18)}$. According to the accumulated data, independent from the removal of the uterus, apical suspension is the required step for successful outcomes ${ }^{(19)}$. Recent studies showed some advantages of sacrohysteropexy including low recurrence rates, absence of mesh erosion, preserving an adequate vaginal length, and maintaining the proper physiological vaginal axis $^{(3)}$. Additionally, laparoscopic hysteropexy was shown to be associated with better anatomic cure rates of higher than $90 \%$ in the majority of the studies. There was an improvement in symptoms, and cure rates of $73-100 \%$ among the patients. Reoperation rates and complication rates were generally low ${ }^{(20)}$. Furthermore, endoscopic approaches have some well-defined advantages including quicker recovery and a reduction in adhesion formation ${ }^{(12,13)}$. Additionally, current laparoscopic techniques provide better and magnified visualization of the anatomy and better hemostasis resulting from intraperitoneal gas pressure(13). In the literature, one of the techniques of laparoscopic ventrosuspension of uterus used the rectus sheath for this purpose. However, according to the reports from the literature, it had unsatisfactory results ${ }^{(21)}$. On the other hand, uterosacral plication and suture hysteropexy were reported to have $80 \%$ success rates ${ }^{(19,22)}$. Recently, total laparoscopic hysteropexy by mesh placement from the upper part of the cervix to the sacral promontory was developed ${ }^{(12)}$. In addition, a published cohort study on the long-term outcomes of laparoscopic versus vaginal mesh hysteropexy revealed high satisfaction rates for both procedures ${ }^{(23)}$. Most hysteropexy techniques have been shown to have high satisfaction and low reoperation rates. It was reported that the type of hysteropexy and possible graft configuration may impact reoperation rates for recurrent prolapse. Furthermore, authors claimed that vaginal mesh risks and the possibility of future hysterectomy with mesh-associated risks should also be considered ${ }^{(24)}$. Moreover, relative to conventional laparoscopic sacral hysteropexy, total laparoscopic hysterectomy with laparoscopic sacrocolpopexy

Table 3. Comparison summary of pre- and post-operative pelvic organ prolapse-quantification classification parameters

\begin{tabular}{|c|c|c|c|c|c|}
\hline & Pre-operative & SD & Post-operative & SD & $\mathrm{p}$ \\
\hline $\mathrm{Aa}(\mathrm{cm})$ & 2.06 & 0.6 & -2.3 & 0.4 & $<0.001$ \\
\hline $\mathrm{Ba}(\mathrm{cm})$ & 3.6 & 1.8 & -2.2 & 1.6 & $<0.001$ \\
\hline$C(\mathrm{~cm})$ & 3.2 & 2.8 & -6.8 & 0.9 & $<0.001$ \\
\hline $\mathrm{pb}(\mathrm{cm})$ & 1.6 & 0.7 & 2.8 & 0.8 & $<0.001$ \\
\hline $\operatorname{tvl}(\mathrm{cm})$ & 7.3 & 0.7 & 7.4 & 2.9 & $>0.05$ \\
\hline Ap (cm) & 1.6 & 1.2 & -2.1 & 0.5 & $<0.001$ \\
\hline $\mathrm{Bp}(\mathrm{cm})$ & 2.4 & 1.7 & -2.3 & 0.7 & $<0.001$ \\
\hline
\end{tabular}

SD: Standard deviation 
procedures were shown to have similar anatomic results, excellent patient satisfaction, and improved quality of life scores ${ }^{(25)}$. Therefore, some modified forms of laparoscopic hysteropexy operations have been introduced.

In their series, Fayyad and Siozos ${ }^{(13)}$ aimed to report the results of a novel technique of hysteropexy using vaginal dissection and mesh placement and fixation of mesh to the sacral promontory via a laparoscopic view. It had some advantages as well as efficacy, especially in patients with cervical elongation and the extra-peritoneal attachment of the mesh to the cervix eliminated the risk of compromise of uterine blood flow. On the other hand, the theoretical disadvantage of this technique is that the insertion of the mesh vaginally can result in increased infection and mesh exposure rates ${ }^{(13)}$.

In their study, Fayyad and Siozos ${ }^{(13)}$ showed that their technique called "VALUES" was free from increased risk of vaginal shortening and narrowing. In addition, the procedure was shown to result in shorter hospital stay and quicker recovery ${ }^{(13)}$. Sacral colpopexy was reported to have a lower risk of recurrent prolapse on examination, redo surgery for prolapse, postoperative stress urinary incontinence, and dyspareunia than a variety of vaginal interventions. However, there is limited evidence to support the use of transvaginal mesh for apical vaginal prolapse repair. There is no consensus on the best access routes for sacral colpopexy. Moreover, there is no clear conclusion on the comparison between uterine-preserving surgery and vaginal hysterectomy for uterine prolapse ${ }^{(26)}$. Recent studies indicated the necessity of randomized controlled studies to show the benefits of laparoscopic sacrocervicopexy with or without supracervical hysterectomy in terms of surgical outcomes and reduced risk of mesh erosion compared with sacrocolpopexy and concomitant total hysterectomy ${ }^{(25,27)}$. Pelvic organ prolapses and stress urinary incontinence were reported to coexist in $80 \%$ of patients with pelvic floor dysfunction ${ }^{(28)}$. We detected coexistence of pelvic organ prolapses and stress urinary incontinence in $36.4 \%$ of cases, which was managed through transobturator tape insertion.

The most difficult part of the procedure during conventional sacrohysteropexy is to dissect the peritoneum down to the cervix. Hemorrhage during this dissection further deteriorates tissue exposure. Furthermore, this partially blinded dissection increases the risk of hypogastric nerve plexus injury. The cervical region in which the mesh is inserted is very close to the rectum, which further makes the procedure difficult. Also, it is difficult to fix the mesh low enough to the cervix in patients with cervical elongation, which results in unsatisfactory results.

\section{Study Limitations}

This study has some limitations, one of them is small sample size and study needs longer follow-up duration.

\section{Conclusion}

VALSH is a safe, minimally-invasive procedure in uterovaginal prolapse that preserves the uterus, enables future normal vaginal delivery, and has shown favorable anatomic and functional outcomes at 12 months follow-up including zero recurrence rates.

\section{Ethics}

Ethics Committee Approval: The study was approved by the Zeynep Kamil Women and Children's Health Training and Research Hospital Local Ethics Committee (approval number: 2015/195).

Informed Consent: Consent form was filled out by all participants.

Peer-review: External and internal peer-reviewed.

\section{Authorship Contributions}

Surgical and Medical Practices: İ.S., M.P., Concept: İ.S., Design: İ.S., Data Collection or Processing: İ.S., Ç.K., M.P., E.Ö., M.D., A.K., Analysis or Interpretation: E.Ö., İ.S., Literature Search: E.Ö., İ.S., Writing: E.Ö., İ.S., M.D., S.G.K.

Conflict of Interest: No conflict of interest was declared by the authors.

Financial Disclosure: The authors declared that this study received no financial support.

\section{References}

1. Digesu GA, Chaliha C, Salvatore S, Hutchings A, Khullar V. The relationship of vaginal prolapse severity to symptoms and quality of life. BJOG 2005;112:971-6.

2. Slieker-ten Hove MC, Pool-Goudzwaard AL, Eijkemans MJ, SteegersTheunissen RP, Burger CW, Vierhout ME. The prevalence of pelvic organ prolapse symptoms and signs and their relation with bladder and bowel disorders in a general female population. Int Urogynecol J Pelvic Floor Dysfunct 2009;20:1037-45.

3. Rosati M, Bramante S, Bracale U, Pignata G, Azioni G. Efficacy of laparoscopic sacrocervicopexy for apical support of pelvic organ prolapse. JSLS 2013;17:235-44.

4. Maher CF, Cary MP, Slack MC, Murray CJ, Milligan M, Schluter P. Uterine preservation or hysterectomy at sacrospinous colpopexy for uterovaginal prolapse? Int Urogynecol J Pelvic Floor Dysfunct 2001;12:381-4.

5. Wilcox LS, Koonin LM, Pokras R, Strauss LT, Xia Z, Peterson HB. Hysterectomy in the United States,1988-1990. Obstet Gynecol 1994:83:549-55.

6. Rardin CR, Erekson EA, Sung VW, Ward RM, Myers DL. Uterosacral colpopexy at the time of vaginal hysterectomy, comparison of laparoscopic and vaginal approaches. J Reprod Med 2009;54:273-80.

7. Dietz V, van der Vaart $\mathrm{CH}$, van der Graaf Y, Heintz P, Schraffordt Koops SE. One-year follow-up after sacrospinous hysteropexy and vaginal hysterectomy for uterine descent: A randomized study. Int Urogynecol J 2010;21:209-16.

8. Feiner B, Jelovsek JE, Maher C. Efficacy and safety of transvaginal mesh kits in the treatment of prolapse of the vaginal apex: A systematic review. BJOG 2009;116:15-24.

9. Moore R, Mitchel G, Miklos J. Single-incision vaginal approach to treat cystocoele and vault prolapse with an anterior wall mesh anchored apically to the sacrospinous ligaments. Int Urogynecol J 2012;23:85-91.

10. Costantini E, Mearini L, Bini V, Zucchi A, Mearini E, Porena M. Uterus preservation in surgical correction of uterogenital prolapse. Eur Urol 2005;48:642-9. 
11. Cutner A, Kearney R, Vashisht A. Laparoscopic uterine sling suspension: A new technique of uterine suspension in women desiring surgical management of uterine prolapse with uterine conservation. BJOG. 2007;114:1159-62.

12. Price N, Slack A, Jackson SR. Laparoscopic hysteropexy: The initial results of a uterine suspension procedure for uterovaginal prolapse. BJOG 2010;117:62-8.

13. Fayyad AM, Siozos CS. Safety and one year outcomes following vaginally assisted laparoscopic uterine sacropexy (VALUES) for advanced uterine prolapse. Neurourol Urodyn 2014;33:345-9.

14. Bump RC, Mattiasson A, Bo K, Brubaker LP, DeLancey JO, Klarskov $\mathrm{P}$, et al. The standardization of terminology of female pelvic organ prolapse and pelvic floor dysfunction. Am J Obstet Gynecol 1996;175:10-7.

15. Özengin N, Kaya S, Orhan C, Bakar Y, Duran B, Ankaralı H, et al. Turkish adaptation of the Pelvic Organ Prolapse Symptom Score and its validity and reliability. Int Urogynecol J 2017;28:1217-22.

16. Wu MP. Laparoscopic uterine suspension for the treatment of uterovaginal prolapse. Int J Gynaecol Obstet 1997;59:259-60.

17. Barranger E, Fritel X, Pigne A. Abdominal sacrohysteropexy in young women with uterovaginal prolapse: Long-term follow-up. Am J Obstet Gynecol 2003;189:1245-50.

18. Seracchioli R, Hourcabie JA, Vianello F, Govoni F, Pollastri P, Venturoli S. Laparoscopic treatment of pelvic floor defects in women of reproductive age. J Am Assoc Gynecol Laparosc 2004;11:332-5.

19. Park AJ, Paraiso MF. Surgical management of uterine prolapse. Minerva Ginecol 2008;60:493-507.
20. Nair R, Nikolopoulos KI, Claydon LS. Clinical outcomes in women undergoing laparoscopic hysteropexy: A systematic review. Eur J Obstet Gynecol Reprod Biol 2017;208:71-80.

21. O'Brien PM, Ibrahim J. Failure of laparoscopic uterine suspension to provide a lasting cure for uterovaginal prolapse. Br J Obstet Gynaecol 1994;101:707-8.

22. Maher CF, Carey MP, Murray CJ. Laparoscopic suture hysteropexy for uterine prolapse. Obstet Gynecol 2001;97:1010-4.

23. Gutman RE, Rardin CR, Sokol ER, Matthews C, Park AJ, Iglesia CB, et al. Vaginal and laparoscopic mesh hysteropexy for uterovaginal prolapse: a parallel cohort study. Am J Obstet Gynecol 2017;216:38. el-38.ell.

24. Gutman RE. Does the uterus need to be removed to correct uterovaginal prolapse? Curr Opin Obstet Gynecol 2016;28:435-40.

25. Pan K, Cao L, Ryan NA, Wang Y, Xu H. Laparoscopic sacral hysteropexy versus laparoscopic sacrocolpopexy with hysterectomy for pelvic organ prolapse. Int Urogynecol J 2016;27:93-101.

26. Maher C, Feiner B, Baessler K, Christmann-Schmid C, Haya N, Brown J. Surgery for women with apical vaginal prolapse. Cochrane Database Syst Rev 2016;10:CD012376.

27. Gutman RE, Rardin CR, Sokol ER, Matthews C, Park AJ, Iglesia CB, et al. Vaginal and laparoscopic mesh hysteropexy for uterovaginal prolapse: a parallel cohort study. Am J Obstet Gynecol 2017;216:38. el-38.ell.

28. Bai SW, Jeon MJ, Kim JY, Chung KA, Kim SK, Park KH. Relationship between stress urinary incontinence and pelvic organ prolapse. Int Urogynecol J Pelvic Floor Dysfunct 2002;13:256-60. 